\title{
Lives twisted out of shape! Tasmanian Aboriginal soldiers and the aftermath of the First World War
}

\section{Andrea Gerrard and Kristyn Harman}

In this article we consider how Tasmanian soldiers of Aboriginal descent experienced the aftermath of the First World War, drawing on and supplementing several case studies from a wider body of research Andrea Gerrard has undertaken into the recruitment and front line experiences of these men. Our particular focus here is to examine how the Repatriation (hereafter 'the Repat') Commission responded to these men post-war. ${ }^{1}$ War changed these men both physically and mentally; literally their lives were twisted out of shape in ways that would have been unimaginable when they initially volunteered. We are particularly interested in interrogating whether the Tasmanian servicemen of Aboriginal descent and their families received treatment equal to that being meted out to other Tasmanian returned servicemen. We unsettle notions that returned Aboriginal servicemen continued to suffer significant discrimination with regard to repatriation benefits in post-war Tasmania, while acknowledging that their particular circumstances may have made the requisite application process more difficult than it was for other Tasmanian returned servicemen. As the Repat records have only recently been made available to researchers, it remains to be seen whether such experiences were distinctly Tasmanian or were emulated across mainland Australia.

\footnotetext{
1 All of the soldiers mentioned in this study are Tasmanian Aboriginal men who form part of a wider study into their enlistment and service during the First World War. This work 'Overlooked: Tasmanian Aborigines in the First World War' has been submitted by Andrea Gerrard for examination to satisfy the requirements of a Masters of Arts at the University of Tasmania.
} 
Genealogical research using a wide range of sources has established that at least 75 men of Tasmanian Aboriginal ancestry volunteered for active service between 1914 and 1918. This number includes four men from Kangaroo Island who were the descendants of Betty Thomas, a Tasmanian Aboriginal woman taken by sealers during the nineteenth century. ${ }^{2}$ From references noted in their personnel dossiers, it became obvious that not all records had survived the intervening years nor their transfer from the Repat in Tasmania to the National Archives at Sydney or Melbourne. In one instance, for example, the file for a war widow could be located but not that of her late husband. ${ }^{3}$ Indeed, around 29 per cent of the men comprising Gerrard's wider study do not have a Repat file, indicating that they made no further contact. This seems to be the case particularly for those who had been discharged for acts contrary to military regulations. For example, Willard Brown, who had been eager to enlist and had made a false statement regarding his age, was later discovered to be younger than his stated years and discharged. Another example is Lionel Cox, who was one of two Tasmanian Aboriginal servicemen to be struck off as a deserter. Other Tasmanian Aboriginal soldiers who appear not to have had any further contact with the Repat were those who were discharged prior to embarkation, being medically unfit. Where they originally existed and have survived the intervening years, the Repat files along with Personnel Dossiers and War Gratuity files form the archival sources for this article.

Our methodological approach builds on the foundations laid by Marina Larsson in her monograph Shattered Anzacs, in which she opened up a new world that many social historians and others had only glimpsed, but that had not previously been fully explored or documented. Through access to the Repat records and talking with families, Larsson revealed many of the horrors that war wrought on the lives of the men who saw front line service, as well as those nearest and dearest to them as it impinged on family life. ${ }^{4}$ In the new edition of Anzac Memories, Alistair Thomson has been able to do something similar through his search for answers about First World War veterans he interviewed in the 1980s. Accessing the Repat records of those he had interviewed earlier also added new understandings of their experiences and how they had constructed their memories of the war. ${ }^{5}$

\footnotetext{
For a full account of Betty and her descendants, including 'Tiger' Simpson, see Taylor 2002.

The file for Alan Montgomery Burgess could not be located despite at least two searches being made for it. Larsson 2009.

Thomson 2013, 2015.
} 


\section{Tasmanian Aboriginality and military service}

During the war, there was a popular myth across Australia that the Tasmanian Aboriginal population had died out with the death of Truganini in May 1876. Yet commentators of the day, according to Russell McGregor, were well aware that people of mixed Tasmanian Aboriginal descent were living on the Furneaux Islands of Bass Strait. ${ }^{6}$ These people were descendants of nine women known to have lived with European sealers on the islands. The survivors increased to a 'sizable population on the islands' and formed a community on Cape Barren Island. In addition, there were 'Aboriginal survivors on mainland Tasmania, who integrated into white society to hide their Aboriginality and have only "come out" again over the last thirty or so years'. ${ }^{7}$ To suggest in the early decades of the twentieth century that on the one hand the race was extinct and on the other to acknowledge the existence of the Straitsmen was not a contradiction in terms at the time, but one that 'followed logically' ways in which race was conceptualised as 'a discrete and bounded entity'. As McGregor explains, so-called mixed-race people were not considered to be authentically Aboriginal people, 'for inclusion demanded that the individual possess all the characteristics supposedly distinctive to the race' ${ }^{8}$

Following the expansion of the Tasmanian land and sea frontiers, the composition and distribution of Tasmania's Aboriginal population became quite distinctive. The Tasmanian government interacted with people of Aboriginal descent differently from their mainland Australian counterparts. For example, unlike most mainland states, no Aborigines Protection Board was established in Tasmania. Instead, a reserve was established on Cape Barren Island in 1881 to accommodate the people of Aboriginal descent known to live there. By the 1900s, in the lead up to the passage of the Cape Barren Island Reserve Act 1912, both the government and the Reserve inhabitants themselves had adopted the now outdated term 'half caste'. On the Tasmanian mainland, some Aboriginal people lived in discrete enclaves, such as the communities that formed in the south of the state comprising descendants of matriarch Fanny Cochrane-Smith, and in the north made up from those descended from Dalrymple Briggs. Others had integrated into wider local communities and in many cases their Aboriginality went unremarked. For these reasons, the question of Aboriginality was possibly not considered by Tasmanian-based recruiting officers during the First World War, and in any case was not noted on any of the Tasmanian attestation papers.

McGregor 1997: 50.

Everett 2000: 2 .

McGregor 1997: 50; Everett 2000. 
Within the wider data set of Tasmanian Aboriginal soldiers, the men's experiences of repatriation varied considerably. This diversity is evident, for example, in briefly considering the case studies of three of these men. While all three were wounded in action, their treatment at the hands of the officers of the Repat and the medical fraternity were quite different. On 12 May 1919, John Rollins MM was discharged from the AIF, having served exactly four years and four months on active service. ${ }^{9}$ Johnson, to use his correct surname, served on Gallipoli for three months before being evacuated to Malta due to illness. He was lightly wounded at Mouquet Farm on 3 September 1916 whilst serving with the 52nd Battalion, hospitalised for scabies and evacuated from the front in April 1918, with a severe bullet wound to his right hand. ${ }^{10}$ In addition, he was awarded the Military Medal for 'bravery and devotion to duty' during operations at Zonnebeke in September 1917 for locating and repairing broken signal wires, thereby ensuring communications at all times. ${ }^{11}$

By way of contrast, James Anderson volunteered for active service on 7 October 1915. Being passed fit, he was allotted to the 40th Battalion, then in the early stages of its formation. On reaching Etaples, France, in October 1916, Anderson was transferred to the 51st Battalion and spent the remainder of the year alternating between front line duty, training and undertaking fatigue duties. On 2 April 1917, the 51st Battalion participated in the 13th Brigade's attack at Noreuil. Anderson suffered a gunshot wound to his left ankle. He was evacuated to England and admitted to the Eastbourne Military Hospital a week later, where he underwent an operation to amputate his left leg below the knee. He left England to return to Australia in 1 November 1917. ${ }^{12}$

'Harry Boy' Brown enlisted on 25 January 1916 with four other Cape Barren Islanders. Embarking with the 12th Battalion, he was later transferred to the 52nd to bring it up to fighting strength before going into action at Mouquet Farm. Here he was wounded for the first time, being evacuated with a shrapnel wound to his left hand. His wound being relatively mild, he was soon back with his battalion. In November 1916, he sustained a shell concussion and burial and was evacuated to England for treatment. ${ }^{13}$ Suffering from headaches, insomnia, tremors, giddiness and some cardiac changes, it was decided that he was not fit to return to the front and was marked out for discharge, which took place in Hobart on 15 September $1917 .^{14}$

\footnotetext{
9 Enlisted using the name John Rollins, legal name Jack Roy Johnson.

10 NAA B2455/1 Personnel Dossier \#1867 John Rollins MM aka Jack Roy Johnson.

11 Australian Gazette, 23 May 1918: 1124, position 172; London Gazette, 14 January 1918: 846, position 151.

12 NAA B2455/1 Personnel Dossier \#332 James Henry Anderson.

13 NAA B2455/1 Personnel Dossier \#5054 Henry George Brown.

14 NAA M1692, Repatriation File Henry George Brown, \#5054, Private, 52nd Battalion.
} 
The war experiences of these men, while quite different, were not out of the ordinary for front line soldiers in the Australian Imperial Force (AIF), particularly for those in the infantry or artillery who enlisted after the end of the Gallipoli campaign. A revision of the casualty figures for the AIF has found that just under half the men (147,000 or 46 per cent) of the 318,100 who enlisted became a battle casualty on at least one occasion. ${ }^{15}$ Of these, around 35,000 were wounded on more than one occasion. While the exact number of Aboriginal men who enlisted during the First World War is not known, to date around 850 men have been identified and their names compiled into one volume by Philippa Scarlett. ${ }^{16}$ The Indigenous Section of the Australian War Memorial estimated that there were approximately 1,300 Aboriginal enlistees, while recent research indicates that the number was probably higher, at around 1,500 men. These enlistees include well-known men such as Douglas Grant or William Punch, who were considered in accordance with the thinking of the time to be 'full blood' Aboriginal men, as well as many who were considered to be 'half-castes' such as the six Lavender brothers from New South Wales.

\section{The federal government's response to the returned soldiers}

During the war years, many promises were made on behalf of the Australian government as inducements to prospective volunteers, assuring them that they would all be well looked after on their return to Australia. While it was never spelt out, it has to be assumed that this was meant to apply to all who enlisted, particularly those who embarked for overseas service. It is likely that many Aboriginal soldiers wondered as they returned home whether they would be eligible for the same benefits as those offered to other soldiers. Perhaps they wondered if they too would be given the same medical care, pensions and other benefits that their other Australian counterparts received.

As wounded and otherwise incapacitated returned soldiers began to arrive home from the front, the initial response on the part of the Australian government was slow. With no comprehensive social welfare scheme in place, the government, in line with thinking that was current at the time, expected that individuals and volunteer organisations would provide relief for soldiers and their dependants. While many individuals provided help and organisations such as the Red Cross became heavily involved, the high number of wounded soldiers returning placed great demands on the limited services that existed. The government soon realised that it needed to assume what would be an unprecedented role, starting with

15 Noonan 2014: 127-128.

16 Scarlett 2013. 
a pension scheme in October 1914, which was more compensatory by its very nature. The government's response arose less through a concern for the welfare of those who had served and their dependants, or to honour any commitments made, but was more pragmatic, with many soldiers who had returned early clearly disaffected at the lack of services or support. They were proving disruptive by threatening to derail the recruitment drive, which was seen as a national priority. ${ }^{17}$ Later, in an attempt to look after those who had served, the government belatedly introduced the Australian Soldiers Repatriation Act 1917 in July 1917 in keeping with what was described at the time as its obligations to 'those who on its behalf have gone down into the Valley of the Shadow of Death and ... of those who heroically fought and suffered in its defence' ${ }^{18}$

While some veterans on their return to Australia refused any connection with the system that had sent them to war, for many the Repat became central to their lives. 'Without the Repat', according to Lloyd and Rees, 'the quantum of human wretchedness, physical pain, mental anguish and poverty in the Australian community over three quarters of a century would have been incomparably greater ${ }^{\prime}{ }^{19}$ This would not always be a positive experience, with many returned veterans having to battle with the Repat in order to have their various medical conditions accepted as war related. ${ }^{20}$ By achieving such recognition, the cost of any associated medical treatment was covered along with some associated financial assistance in the form of a pension or an increase in an existing benefit if required.

\section{The inception of the Repat}

Australia's response to the mass of incapacitated men was the introduction of the Repatriation Health Care Service. The scheme operated and continues to do so in conjunction with other areas of the Repat including vocational training, welfare support and pensions. Approvals for pensions were dependent on medical examinations that went beyond simply defining the nature and extent of the veteran's incapacity. Only illness or injuries established as being related to a veteran's war service were treatable and compensable under the Repatriation scheme. As Thomson points out, 'strictly speaking, the war pension was neither a pension nor an entitlement'. While it provided some compensation for the loss of earning capacity, its aim at least prior to 1936 was to 'create self-reliant

17 Richardson 2005; Lloyd and Rees 1994.

18 Australian Soldiers' Repatriation Act 1917 (Cth); Commonwealth Parliamentary Debates, 18 July 1917:

195; Lloyd and Rees 1994: 5.

19 Lloyd and Rees 1994: 419.

20 Larsson 2009; Blackmore 2008; Thomson 2013. 
citizens who were not dependent on charity' ${ }^{21}$ While the medical aspect of the Repat was aimed at repairing as far as was practicable the bodily damage caused by war, the process of obtaining the medical, hospital and pension assistance was at times very confronting, confrontational and intensely personal.

In order to apply for benefits, veterans needed to visit an accredited doctor (Local Medical Officer) to undertake a cursory medical examination to ascertain any incapacity in line with the veteran's claim. Upon receipt of the doctor's report, arrangements would then be made for the person to be seen by a Medical Officer from the Repat, at which time a detailed examination took place. The next step in the process, and possibly the most important, was the compilation of the reports to assess the nature and extent of any incapacity, and whether it was due to war service. This information was then sent to the Board for approval or rejection. As part of the examination, the veteran was asked to state his service history and the cause of his incapacity, which was then compared with their medical records. One problem, that few if any of the veterans would have been aware of, was that many of the AIF's most important wartime medical records had been mistakenly destroyed in London in 1919. Despite this, the onus of proof was on the veteran, who then had to use his body to prove his claim that his injury or illness was due to his war service. For many returned servicemen, the whole process was disempowering and even alienating, particularly when claims were rejected. For those who had their claims accepted, it was necessary under the Repat regulations to reduce the incapacity or suffering to a number that equated to a particular pension rate. ${ }^{22}$

\section{Aboriginality and Repat entitlements}

The Repat status of Aboriginal men who had served in the AIF was a question that exercised the minds of some bureaucrats in the aftermath of the war, particularly given their status under the control of state regimes. Service in the AIF did not change the citizenship status of mainland Aboriginal veterans in particular, with many on their return continuing to have their activities restricted by various state legislations. As Noah Riseman has recently illustrated, institutional and individual racial discrimination experienced by Aboriginal returned servicemen extended to their families as well. In some instances, quarantined monies were not paid out, contributing to the wider phenomenon that has since become known colloquially as the 'stolen wages'.$^{23}$

\footnotetext{
21 Thomson 2013: 285.

22 Andrea Gerrard was the one-time Officer in Charge of Medical Records at the Repatriation General Hospital in Hobart, Tasmania.

23 Riseman 2014: 188-189.
} 
It did, though, according to Lloyd and Rees, 'give the Aboriginal war veteran entitlement to repatriation benefits'. This was made clear by Repatriation Commissioner Gilbert in 1919, when he pointed out that while an Aboriginal man who had served in the AIF might come under the care and supervision of the state Protection Board, he was still 'entitled to the benefits under the Australian Soldiers Repatriation Act', and therefore could not be denied the 'full use and enjoyment of any benefits granted to him' by the Repat. ${ }^{24}$ As Lloyd and Rees acknowledge, this would seem a very enlightened policy given the standards of the time, but they have also expressed doubts about its implementation, given the dearth of evidence uncovered to date as to how this was applied. It would seem though, that it might not have been applied equally across the board, with sporadic complaints being made about discrimination against Aboriginal war veterans during the 1920s and 1930s. ${ }^{25}$

\section{Repat processes and procedures}

On their return to Australia, men were required to undergo an examination shortly after leaving the ship. In one case cited by Alistair Thomson, nonAboriginal soldier Bill Langham was taken straight from the ship to the Sturt Street Barracks to be examined. Desperate to join his family after a two hour wait, Langham told them that he did not care what they graded him as long as he was free to leave immediately. While Langham later re-established contact with the Repat over an eye injury, others shunned the services that might have been offered to them. ${ }^{26}$ One such Aboriginal soldier was George Enos Mansell from Flinders Island. Despite being wounded in action at Mouquet Farm whilst serving with the 52nd Battalion, post-war he did not expose his body or his history to questioning by the Repat. ${ }^{27}$ This may have been due to the geographical remoteness of his location compared with the nearest Repat centre, which was situated in Launceston in the north of Tasmania.

Another example is Edward Rees, who initially made contact with the Repat, but made no further claims even though he was wounded in action on two occasions. It is possible that his incarceration for desertion in 1918 may have been a contributing factor, potentially souring any relationship he had with the military, which for many included the Repat. ${ }^{28}$ While remoteness was certainly

\footnotetext{
24 Lloyd and Rees 1994: 107.

25 Lloyd and Rees 1994: 107.

26 Thomson 2013: 290. Langham is the only non-Aboriginal soldier referred to in this article. The remaining men are all of Tasmanian Aboriginal descent.

27 NAA B2455/1 Personnel Dossier \#5149 George Enos Mansell. Any further record of file No. R6748 has not been found.

28 NAA R10512 Repatriation File Edward Rees \# 4356, Lance Corporal, 12th Battalion.
} 
a factor in not contacting the Repat for some of the Furneaux Islanders, who relied on a weekly shipping service and would have had trouble attending necessary appointments on mainland Tasmania, for others such as George Fisher, it was demonstrably not an issue. Fisher, a Cape Barren Island inhabitant, had a long history of contact with the Repat from his return to Australia until his death in 1964.

Poor literacy skills might explain why William Elmer, who according to his obituary notice suffered poor health as a result of his 'war disabilities', had not made any further claims on the Repat for his ongoing health care. ${ }^{29}$ The only claim he personally made was for some mining tools to enable him to be selfemployed. Many years later, the local Returned Sailors and Soldiers Imperial League of Australia (hereafter RSSILA) sub-branch submitted a claim for his funeral expenses when he died in August 1941. ${ }^{30}$ However, being illiterate was not an impediment to William Stanton from Nichols Rivulet. No doubt with help from his brother, William managed to access sustenance payments whilst trying to get the soldier settlement block he shared with his brother Harold up and running. ${ }^{31}$ In fact, the Stanton brothers managed to access a range of support which included help with school fees as well as funeral expenses for their mother. ${ }^{32}$

On returning to Australia, James Henry Anderson was granted a pension at 100 per cent in respect of the loss of a lower limb. Six months later this was reduced to 75 per cent. Anderson, with little education, was then forced to return to manual labour. By age 55 he was struggling to hold down a job due to his disabilities, but the Repat refused his application for a Special Rate Pension and continued to do so despite agreeing that by age 60 he was unemployable. ${ }^{33}$ A later claim for peripheral vascular disease was accepted. There is no mention of Aboriginality in his files, so this suggests that rather than discrimination based on race, this case involved a lack of empathy. As Larsson has explained, those from the working class who had partial disabilities were at the highest risk of being unemployed as they had formerly depended on their bodily strength for their livelihoods and were now no longer in a position to do so to the same extent. $^{34}$

29 NAA B2455/1 Personnel Dossier \#315 William Elmer.

30 NAA R7806 Repatriation File William Elmer \#315, Private, 40th Battalion; Advocate, 27 August 1941: 2.

31 NAA P130 R4225 \#2310 William Alfred Stanton, Private, 40th Battalion.

32 NAA P130 R4225 \#2310 William Alfred Stanton and P130 R5098 \#2341 Harold Joseph Stanton, Private, 40th Battalion.

33 NAA R310 Repatriation File James Henry Anderson, \#332, Private, 40th Battalion.

34 Larsson 2009: 102. 
In February 1917, in England, Henry George Brown was assessed as being permanently unfit for general service, having been diagnosed with shell shock and burial. He was sent back home and discharged at Launceston in September 1917. Brown was granted a 50 per cent pension for a period of six months. Later the Repat sought a medical opinion from the doctor on Cape Barren Island where Brown resided, but also took the unusual step of asking the local police for a report into Brown's activities. The doctor reported that Brown was incapacitated and suffering from 'war shock and ear trouble' and had 'lost his earning power to the extent of the whole'. The local policeman reported that Brown had spent eight weeks catching muttonbirds during the birding season which implied that he was in 'good health and quite able to work' ${ }^{35}$ With conflicting reports having been provided, his pension was continued at 50 per cent until June 1919, when more claims were made that he had again been muttonbirding and had also completed a brief stint at tin mining. In August 1920 his pension was reduced to 25 per cent. In 1921 Brown complained to the Repat that the $10 / 6$ he received weekly was not sufficient to live on. However, at the end of the year his pension was cancelled altogether. In June 1930, through help from the General Secretary of the RSSILA, Brown applied for his pension to be restored, which occurred later that year, again at 25 per cent. In Brown's case, his complex interactions with the Repat seem, at least in part, to have been inflected by race in that further evidence of his activities was requested from the local police. His engagement in traditional cultural activities was taken as evidence of his capacity to work and therefore his reduced need for financial support.

Not all applications claiming illnesses or diseases were accepted as war related by the Repat, and many had their claims rejected. But this did not prevent some from reapplying or appealing against the decisions, as in the case of Julian Everett who served with the 12th Battalion. Everett appealed against the decision made in November 1947 to grant him a 60 per cent pension on account of his inability to work due to congestion, weakness and shortness of breath. As a result of his lodging an appeal, Everett was required to travel to Hobart and spend time in the Repatriation General Hospital while further tests were carried out. Everett lost his appeal for a further increase and continued to be in receipt of a 60 per cent pension rate until his untimely death from drowning. ${ }^{36}$

35 NAA R755 Repatriation File Henry George Brown, \#5054, Private, 52nd Battalion.

36 NAA P130 R1567 Repatriation File Julian Clifford Everett \#6271, Private, 12th Battalion. 


\section{Finding employment for returned soldiers}

The issue of finding employment for the returned soldiers was one that exercised the minds of many from the time the first wounded men returned from Gallipoli. In August 1915, the Federal War Committee had raised the issue of employment for returning men and the obligations and responsibilities that it had in assisting with providing this. Senator Millen reiterated this point again in December 1918 when calling on the Australian public to assist in its 'duty of the nation', impressing on them the importance of providing employment to returning soldiers as part of the Repatriation process. He stated that all Australians needed to, and could, help with this, including local and state government bodies. ${ }^{37}$ While some men like William Henry Mansell had taken up the offer of educational and training programs in Britain as they waited for the next boat home, it was not until after they were discharged that the Repat was prepared to accept some responsibility. ${ }^{38}$ For example, Mansell, a Cape Barren Islander, obtained work with $\mathrm{H}$. Childs, a firm of painters and decorators at Reading in England. However, he appears not to have used these skills to find work once back home. He may not have found much demand for painting and decorating in the immediate aftermath of the war.

Many who had returned home early to Tasmania were at a disadvantage despite calls to employers for returned soldiers to be given preference over civilians when employing staff or issuing contracts, even long before this was enshrined in legislation. Historian Lloyd Robson has referred to the 1920s as Tasmania's 'Dismal Decade', but its economic decline had begun at about the same time as many of the men left with the first contingent. ${ }^{39}$ Despite two new industries having emerged in the state - the Electrolytic Zinc Company and the Cadbury Chocolate factory - the industrial and manufacturing base remained small and the labour market very tight. ${ }^{40}$

In order for the Repat to help with finding employment, a soldier was required to register and report on a daily basis until finding work. If more than a week lapsed, then a graded sustenance allowance was usually granted to support the returned soldier, and his family if married. Prior to 1919, this sustenance allowance was generally continued for as long as the returned soldier was looking for work. ${ }^{41}$ Again it appears that sustenance payments and help in securing employment were extended to the Tasmanian Aboriginal soldiers if they chose to apply. Yet this help did not extend to the Cape Barren Islanders

\footnotetext{
37 The Mercury (Hobart), 18 December 1918: 4.

38 According to NAA B2455/1 Personnel Dossier \#3356 William Henry Mansell.

39 See chapter 1 in Lake 1975.

40 Electrolytic Zinc Works started in 1916, and Cadbury's confectionery plant in 1920. See Alexander 1992.

41 Richardson 2005: 200.
} 
when they returned to their island homes. With no industry or ongoing forms of employment available on the island, the Cape Barren veterans had to use their own networks to secure seasonal or casual work. None applied for sustenance payments or other benefits whilst out of work. Another Aboriginal soldier who was formerly a labourer prior to the war took advantage of the opportunity to learn a trade through engaging in an employment scheme. Jack Roy Johnson MM, who had returned from the war having sustained a gunshot wound to his right hand and ongoing problems with the varicose veins in his left leg, relocated to Hobart and undertook a fitting and turning class at the Hobart Repatriation Trades School. He learned some basic skills and then became an industrial trainee with the Hydro-Electric Power and Metallurgy Company at Electrona, south of Hobart, earning 40 per cent of the award rate. He was then taken on with the Hydro-Electric Department (later Hydro-Electric Commission) before moving to the Electrolytic Zinc Company at Risdon, near Hobart, where he was paid 65 per cent of the award rate. His wages were brought up to the minimum award rate by the Repat. His services were dispensed with owing to the curtailment of construction work at the plant, but he was later reinstated. Frequent periods of ill health affected Johnson's employment history, forcing him to rely on sustenance payments from the Repat when not covered by his leave entitlements. ${ }^{42}$ Despite his ongoing health issues, Johnson was, having availed himself of assistance through retraining under the Repat employment scheme, able to hold down a variety of jobs until his eventual retirement, albeit with his income being supplemented by the Repat.

In July 1921, Frederick Brown, a Tasmanian Aboriginal man living on Cape Barren Island, lodged a claim for a loan from the Repat for the purchase of a boat to help him earn a living. According to Brown the sum required was not large, just $£ 75$ for a 27 -foot cutter which he claimed was in first-class order. His application was refused because he had not proved that he was involved in the fishing industry prior to enlistment, nor had he owned a boat on enlisting. Also taken into consideration was the fact that in order to be eligible, he should have applied within 12 months of being discharged. The Repat was not opposed to helping him if he could produce the necessary proof. Seeming to have lost interest in pursuing work as a fisherman and preferring instead to pick up labouring work when it was available, Brown took no further action. ${ }^{43}$

42 NAA R4618 Repatriation File Jack Roy Johnson (alias Rollins) \#1867, Lance Corporal, 52nd Battalion.

43 NAA R10525 Frederick William Brown, \# 3427, Private, 40th Battalion. 


\section{War gratuities}

A reading of the related war gratuity files held by National Archives (series P1868) suggests that in all probability the dependents and beneficiaries of the Tasmanian Aboriginal soldiers who died whilst on active service were paid all the benefits to which they were entitled, but this was not the case Australia-wide. In a number of cases, financial benefits that were paid to the soldier or to his dependents were controlled by the various state Protectors of Aborigines or even the Repat itself, as Aboriginal people were usually treated as wards of the state. Doreen Kartinyeri in her study of the Ngarrindjeri Anzacs from South Australia cites the case where one dependent had her payments controlled by the Repat. ${ }^{44}$ In the case of Alex McKinnon, 43rd Battalion, who was killed at Passchendaele, his gratuity was eventually granted to his mother Alice (Cobb) in 1922, but was to be paid to the Protector of Aborigines and not directly to Alice. His medals were given to his stepmother Mary, a woman he had had no contact with, despite McKinnon having given Alice as his next of kin and having made her his beneficiary. ${ }^{45}$ There is no evidence of this happening in Tasmania where there was no Protector of Aborigines to control Aboriginal lives. Tasmanian Aboriginal people living on the Cape Barren Island reserve had some controls placed on their movements, but not in the same way as mainland Aboriginal people.

In 1915 and 1916 following the disastrous Gallipoli campaign, the payment of allowances and pensions was not always carried out in a timely manner, as bureaucracy came to terms with dealing with the aftermath of mass deaths. ${ }^{46}$ Ida Miller, widow of Tasmanian Aboriginal Private John Miller, reported 'missing in action' at the landing at Anzac Cove, claimed the allotment that he had set aside to provide for her and their family of four young children. ${ }^{47}$ The allotment was an interim measure until a pension was awarded. In June 1915 the rules changed, and allotments were to cease 'exactly two months' after notification of the death of a soldier, though bona fide dependents could gain an extension of a further two months. ${ }^{48}$ At the end of February 1916, Miller's allotment ceased. With four little children under the age of four to provide for, she turned to the head teacher at Kellevie, near Sorell, to help her. ${ }^{49}$ After applying to the Deputy Commissioner of Pensions, it was decided to reinstate the allotment until such time as a pension could commence. In order to receive the pension, Miller had to wait until after the determination of the Court of Inquiry, which sat

44 Kartinyeri 1996: 30-31.

45 NAA B2455/1 Personnel Dossier \#2230 Alexander McKinnon.

46 NAA P1868 series War Gratuity Files.

47 NAA P1868 / 1 War Gratuity File \#T13336 John William Miller.

48 Stanley 2014: 245.

49 Ida Miller née Bloomfield had been born at Kellevie and may still have had family living there. 
in Alexandria in June $1916 .{ }^{50}$ Her experience was not unusual, particularly among the widows and families of those killed in action at the landing at Anzac Cove, who had to wait years in some cases while enquiries were made and determinations put in writing before pensions could begin to be paid. ${ }^{51}$ Families, if able, were expected to help in the meantime, but many widows, Aboriginal and non-Aboriginal alike, were forced to go cap-in-hand to charities, such as the Red Cross, for assistance with procuring food and rent, in the short term at least.

At the outbreak of the war it was not uncommon for a son or sons to be supporting one or both parents when they enlisted. On the death of their son, it was up to the mother (or in some cases the father) to prove that they had been supported by their son for at least 12 months prior to enlistment. Alicia Maynard from Cape Barren Island, mother of Tasmanian Aboriginal soldier Edward, proved that her son had been supporting her and was granted a pension following his accidental death in August 1915. ${ }^{52}$ Eva, Alicia's sister, also lost two sons who had been supporting her. She was granted $£ 2$ per fortnight following the death of Frank at Pozieres in August 1916, and a further 40/- when William was killed in action in April 1917. ${ }^{53}$

While most parents or widows applied for the gratuity and other entitlements owing to their deceased sons, two fathers appear not to have applied for the gratuity payment or other entitlements for their Tasmanian Aboriginal sons, a situation which, while not common, was not necessarily that unusual either. While illiteracy may have been an issue for some families, it would not appear to have been so in the case of James Gower, who claimed the gratuity for one son who died of wounds, but not for the other son who died of illness. Why Gower did this is unclear from the remaining records. ${ }^{54}$ While the money families received would be small compensation for their loss, it did in many cases help the dependents, at least in the short term.

Depending on the situation, some gratuities were paid in bonds, while others were paid out in cash. Henry William Brown and Peter Mansell both petitioned for the amount owing to be paid to them in cash in order to settle outstanding

\footnotetext{
50 NAA P1868/1 War Gratuity File \#T13336 Private John William Miller.

51 Stanley 2014: 244-251.

52 NAA B2455/1 Personnel Dossier \#2294 Edward Lewis Maynard \& P1868/1 War Gratuity \#T13269 Edward Lewis Maynard.

53 NAA B2455/1 Personnel Dossier \#1153 Frank Maynard \& P1868/1 War Gratuity \#T13270 Frank Maynard; B2455/1 Personnel Dossier \#6311William Samuel Maynard \& P1868/1 \#T13271 William Samuel Maynard.

54 James Gower claimed the gratuity for his son John Donald Gower who died of wounds in July 1916, but not for William Harold Gower who died of illness in November 1918.
} 
debts that they had to local shopkeepers for provisions bought on credit. ${ }^{55}$ As a muttonbirder, a traditional occupation among Tasmanian Aboriginal people, Mansell had not earned anything since the end of the last season. During the off season, many of the Cape Barren Island families purchased stores or other items on credit. By early 1920, Mansell had debts that extended back to 1918 and wanted help to finalise these. Brown claimed that since the war two sons had left home to get married and were no longer assisting him in muttonbirding. Unable to work on his own account, he was by June 1921 forced to work for wages that had been seized to cover his debts. ${ }^{56}$ This left him with no money to purchase provisions for himself, his wife and four unmarried children until the next muttonbird season. There is no evidence on file to suggest that these requests were denied.

\section{Tasmanian Aboriginal soldiers, racism, and the Repat}

There are no recorded statements to indicate that any concerns about race underpinned the Repat's decisions in relation to Tasmanian Aboriginal soldiers. However, there are some demonstrable instances of racial discrimination impacting on their lives during the process of applying for benefits. For example, the medical officer servicing Cape Barren Island described William Mansell as a 'half-caste' with a 'poor physique, very little stamina which is natural with this type of man from the island' ${ }^{57}$ Another local medical officer was of the opinion that all Cape Barren Islanders had a poor diet and were lacking in vegetables and fruit. Clearly, this doctor had not talked to or spent time with these men. Several accounts of island life during the interwar years, such as those of Molly Mallet and Ida West, refer to the vegetable gardens kept by their fathers. ${ }^{58}$ As Thomson discovered when accessing the Repatriation records, the files are 'crowded with moral judgements about family traits'.$^{59}$ How well Dr G. H. Key knew William Mansell is unclear. It would appear, though, from other comments made in the file that he had not had a lot of contact with him but had formed an opinion about the Islanders, which clearly exhibits racial prejudice. Despite many of the staff, including medical officers, being war veterans, any sympathy they might have had for these returned men was 'tempered by their bureaucratic role and by the social background and values'. Most medical officers shared a

55 NAA P1868/1 \#T12236 Brown, Marcus Black Norman 40th Battalion, Application for War Gratuity; NAA P1868/1 \#T5351, Mansell Morgan 40th Battalion, Application for War Gratuity.

56 NAA P1868/1 \#T12236 Brown, Marcus Black (Blake) Norman, Statutory Declaration dated 24 June 1921.

57 NAA P130 R9467 Repatriation File William Henry Mansell \#3356, Private, 40th Battalion.

58 Mallett 2001; West 2004.

59 Thomson 2013: 286. 
'set of conservative and "militaristic" social values about hierarchical authority, personal responsibility and moral character', that saw them situate Aboriginal people low down the social scale. ${ }^{60}$

\section{Conclusion}

In Tasmania, evidence garnered so far from Personnel Dossiers, Repat records, and other subsidiary records suggests that Gilbert's statement of 1919 - that Aboriginal veterans were entitled to the same repatriation benefits as other soldiers - seems to have applied across the board. By and large, Tasmanian Aboriginal veterans received on application the same benefits that they were entitled to post-discharge as other veterans, in accordance with the schedules set out under the legislation. ${ }^{61}$ However, for some, factors such as geographical isolation, poor literacy rates arising from historic socioeconomic disadvantage, and the confronting elements of the process impacted on their capacity and will to complete or contest applications. In some cases, the application process was fraught with medical officers exhibiting elements of racial prejudice in preparing the necessary reports. In at least one case, it was probably his Aboriginality that saw Henry George Brown kept under an increased level of surveillance and discriminated against on the basis of his having engaged in a traditional cultural activity that allegedly proved his health was better than he had claimed.

In Tasmania, gratuities and other payments were made directly to the beneficiaries, regardless of race, unlike some instances cited from the mainland. Evidence also demonstrates that some Tasmanian Aboriginal returned servicemen successfully applied to lease land under the Settlement Scheme. If there was any discrimination or lack of understanding on the part of the Repat, it was in requiring Cape Barren Islanders to travel to Launceston, let alone Hobart, which was even farther away, for assessment or treatment. It would appear few, if any, officers involved in organising transportation for these men had any idea of the remoteness of Flinders and Cape Barren Islands, or knew that (in this era before a regular air service) shipping called only on an irregular basis. Leaving the island was at times a feat in itself. The men, though, were connected to this land, which was, after all, their home.

60 Blackmore cited in Thomson 2013: 286.

61 The Australian Soldiers' Repatriation Act 1917 has four schedules attached to it setting out general pension rates, rates for special pensions and rates payable for those who are incapacitated. 


\section{References}

\section{Primary Sources}

\section{National Archives of Australia}

NAA B2455/1 Personnel Dossiers:

\#1867 John Rollins MM (aka Jack Roy Johnson)

\#332 James Henry Anderson

\#5054 Henry George Brown

\#1340 Cyril Allen Johnson

\#5149 George Enos Mansell

\#4356 Edward Rees

\#315 William Elmer

\#889 George Leonard Johnson

\#2294 Edward Lewis Maynard

\#1153 Frank Maynard

\#6311 William Samuel Maynard

\#3356 William Henry Mansell

\#2230 Alexander McKinnon

\section{Repatriation Files}

P107 Series:

M1692 \#5054 Henry George Brown, 52nd Battalion

P130 Series:

R10512 \#4356 Edward Rees, Lance Corporal, 12th Battalion

R7806 \#315 William Elmer, Private, 40th Battalion

R4225 \#2310 William Alfred Stanton, Private, 40th Battalion

R5098 \#2341 Harold Joseph Stanton, Private, 40th Battalion

R4618 \#1867 Jack Roy Johnson (alias Rollins), Lance Corporal, 52nd Battalion 
ABORIGINAL HISTORY VOL 392015

R10525 \#3427 Frederick William Brown, Private, 40th Battalion

R1567 \#6271 Julian Clifford Everett, Private, 12th Battalion

R9467 \#3356 William Henry Mansell, Private, 40th Battalion

War Gratuity Files (P1868 Series):

\#T13336 Private John William Miller, 12th Battalion

\#T13269 Private Edward Lewis Maynard, 15th Battalion

\#T13270 Private Frank Maynard, 26th Battalion

\#T13271 Private William Samuel Maynard, 12th Battalion

\#T12236 Private Marcus Black Norman Brown, 40th Battalion

\#T5351 Private Morgan Mansell, 40th Battalion

\section{Legislation}

Australian Soldiers' Repatriation Act 1917 (Cth)

\section{Newspapers}

The Advocate

Australian Gazette

London Gazette

The Mercury (Hobart)

\section{Secondary sources}

Alexander, Alison 1992, The Zinc Works: Producing Zinc at Risdon 1916-1991, Pasminco-Metals EZ, Risdon.

Blackmore, Kate 2008, The Dark Pocket of War: War, Medicine and the Australian State 1914-1935, Lythrum Press, Adelaide.

Crotty, Martin and Marina Larsson (eds) 2010, Anzac Legacies: Australians and the Aftermath of War, Australian Scholarly Publications, North Melbourne.

Everett, Jim 2000, Siglo 12: 1-6.

Gammage, Bill 2010, The Broken Years: Australian Soldiers in the Great War, Melbourne University Press, Melbourne. 
Larsson, Marina 2009, Shattered Anzacs: Living with the Scars of War, University of New South Wales Press, Sydney.

Lloyd, Clement and Jacqui Rees 1994, The Last Shilling: A History of Repatriation in Australia, Melbourne University Press, Carlton.

McGregor, Russell 1997, Imagined Destinies: Aboriginal Australians and the Doomed Race Theory, 1880-1939, Melbourne University Press, Clayton South.

Mallett, Molly 2001, My Past - Their Future: Stories from Cape Barren Island, Blubberhead Press, Sandy Bay.

Noonan, David 2014, Those We Forget: Recounting Australian Casualties of the First World War, Melbourne University Press, Carlton.

Kartinyeri, Doreen 1996, Ngarrindjeri Anzacs, South Australian Museum and Raukkan Council, Adelaide.

Richardson, Andrew 2005, 'The Long Road Home: Repatriation in Tasmania 1916-1929', unpublished PhD thesis, School of History and Classics, University of Tasmania.

Riseman, Noah 2014, 'Enduring silences, enduring prejudices: Australian Aboriginal participation in the First World War', in Endurance and the First World War: Experience and Legacies in New Zealand and Australia. David Monger, Katie Pickles and Sarah Murray (eds), Cambridge Scholars Publishing, Newcastle upon Tyne, 178-195.

Scarlett, Philippa 2013, Aboriginal and Torres Strait Islander Volunteers for the $A I F$, Indigenous Histories, ACT.

Stanley, Peter 2014, The Lost Boys of Anzac, NewSouth Publishing, Millers Point.

Taylor, Rebe 2002, Unearthed: The Aboriginal Tasmanians of Kangaroo Island, Wakefield Press, Adelaide.

Thomson, Alistair 2013, Anzac Memories: Living with the Legend, Melbourne University Publishing, Clayton.

Thomson, Alistair 2015, 'Anzac Memories Revisited: Trauma, Memory and Oral History', Oral History Review 42(1): 1-29.

West, Ida 2004, Pride against Prejudice: Reminiscences of a Tasmanian Aboriginal, Montpelier Press, North Hobart. 
This text is taken from Aboriginal History, Volume 39, 2015, edited by Liz Conor, published 2015 by ANU Press,

The Australian National University, Canberra, Australia. 